\title{
Effect of Counseling Packages on The Diet of Pregnant Women With Chronic Energy Deficiency
}

\author{
Risqi Dewi Aisyah*, Suparni Suparni, Fitriyani Fitriyani \\ Universitas Muhammadiyah Pekajangan Pekalongan, Indonesia \\ *aisyahrisqidewi@gmail.com
}

\begin{abstract}
Pregnancy is the most important in terms of nutrition of each woman's lifetime. Proper nutrient intake during this period has an important role in fetal development. Malnutrition during pregnancy using short- and long-term effects on a baby's health increases the risk of unexfected diseases, and is closely related to the survival of mothers and their babies This type of research is a pseudo experiment (quasy experiment) that researchers measure variables before a counseling package. The design of this study is Observational Analytics. The sample in this study used non probability sampling techniques of consecutive sampling type namely 30 pregnant women who experienced chronic energy deficiency in Puskesmas Kedungwuni II. Data collection using cheklis food recal taken from kek countermeasure manual. The data analysis technique to be used is by univariate and bivariate test with T-Test test. The results of the study obtained a value of $\mathrm{p}=0.001(<0.05)$ with a confidence interval of $95 \%$ can be concluded that Ho was rejected and Ha accepted which means there is a very significant difference between the diet of respondents before and after the provision of counseling packages to the diet of pregnant women with KEK. It is expected for midwives to provide more in-depth counseling and continuous monitoring to pregnant women who are chronically deficient, in order for dietary changes so that nutrition during pregnancy can be met.
\end{abstract}

Keywords : Pregnancy, Chronic Energy Deficiency, Counseling 


\section{STRADA Jurnal Ilmiah Kesehatan}

DOI: $10.30994 /$ sjik.v9i2.399

ISSN: 2252-3847 (print); 2614-350X (online)

Vol.9 No.2 November 2020 Page.944-949

\section{BACKGROUND}

Pregnancy is the most crucial nutritionally demanding period of every woman's life. Appropriate nutrient intake during this period has a critical role in fetal developmentand better maternal nutritional status. Failure to receive necessary micro- and macronutrient during this period will result in undernutrition and adverse pregnancy outcome. Undernutrition during pregnancy wields both shortand long-term effects on the health of an infant by programming the infant's development, increases the risk of noncommunicable diseases, and is intimately related to the survival of both mothers and their babies. Undernourished mothers are more vulnerable to diseases, encounter more miscarriages, and give birth to underweight children whose survival is at risk (Diddana et al, 2018).

Nutrition plays a major role in maternal and child health and it is widely recognized that optimum nutrition in early life is the foundation for longterm health. A healthy maternal dietary pattern, along with adequate maternal body composition, metabolism and placental nutrient supply, reduces the risk of maternal, fetal and long-term effects in the offspring. While undernutrition is mainly an issue of low-income countries, malnutrition, due to poor quality diet, is becoming a global health problem (Cetin I \& Laoret A 2015).

The nutritional status of the mother at conception is a key factor for development and foetal growth, so a healthy, balanced diet is essential both before and during pregnancy. During pregnancy, the mother's diet provides energy and nutrients to both herself and the foetus' growth and for future lactation. From the data in the literature, the linking between nutrition during foetal life and the potential risk of disease in adulthood emerged (Castrogiovanni and Imbesi, 2017)

Maternal nutrition during pregnancy, and how this impacts placental and fetal growth and metabolism, is of considerable interest to women, their partners and their health care professionals. In developing countries, maternal undernutrition is a major factor contributing to adverse pregnancy outcomes. Conversely, with the increased prevalence of high calorie diets and resulting overweight and obesity issues in developed countries, the impact of this overnutrition situation upon pregnancy outcome is highlighted as a contributing factor for adverse metabolic outcomes in offspring later in life. Further, while low or excessive food intake per se is an important aspect of pregnancy development, the specific role that the placenta plays in nutrient metabolism and overall nutrient supply to the fetus in situations of undernutrion, overnutrition or poor diet composition is still poorly defined. Both epidemiology and animal studies now highlight that undernutrition, overnutrition, and diet composition negatively impact fetoplacental growth and metabolic patterns, having adverse later life metabolic effects for the offspring. This issue aims to highlight new research in a number of these abovementioned areas across the early life course (Morison and Regnault, 2016).

The nutritional status of pregnant women are affected by daily nutritional intake. Nutrient intake during pregnancy is different with nutrient intake before pregnancy. Daily nutritional intake during pregnancy depends on total macronutrient intake and micronutrient intake such as iron, folic acid, cobalamin (B12), vitamin D, iodium, calcium, vitamin A and zinc (Rahfiludin dan Dharmawan, 2019)

Pregnancy is a critical period during which maternal nutrition has a major effect on a mother's and baby's health. Lack of adequate nutrition of good quality and quantity during pregnancy can cause health problems for both the mother and her fetus. Maternal malnutrition increases the risk of gestational anemia, hypertension, miscarriages and fetal deaths during pregnancy, pre-term delivery and maternal mortality. For newborn, it can 


\section{STRADA Jurnal Ilmiah Kesehatan}

DOI: $10.30994 /$ sjik.v9i2.399

ISSN: 2252-3847 (print); 2614-350X (online)

Vol.9 No.2 November 2020 Page.944-949

cause low birth weight, fetal intrauterine growth retardation that may have long life consequences on newborn development, quality of life and health care costs. Malnutrition also has an adverse effect on the development of the immune system of the newborn. (Salem S, Eshra D and Saleem N, 2016). Poor diet with lack of nutrient supplementation during pregnancy would worsen maternal malnutrition (Desyibelew and Dadi, 2019)

Maternal nutritional and metabolic factors affect the developmental process of the fetus which consequently influence the birth weight of the newborn. During pregnancy, many physiological and metabolic functions are changed to a great extent. Pregnant women need adequate energy and nutrients to meet the increased nutritional demands for growth of the fetus and to satisfy the increased body demands of the mother. Poor maternal nutritional status has been related to different adverse birth outcomes including intrauterine growth restriction and low birth weight (LBW), which can have lifelong consequences for development.Thus, improving maternal nutritional status before conception and during pregnancy are essential to improve birth weight of newborns (Woldeamanue et al, 2019)

One of the efforts to help pregnant women with malnutrition is with education and counseling. Without improving nutritional knowledge, dietary practices, and dietary behaviors performed during pregnancy, it may be difficult to achieve proper nutritional adequacy. Counseling is done with the aim of helping pregnant women reduce barriers in nutritional fulfillment, and with counseling there is a change in negative behavior to positive. The results showed that providing education and counseling can improve the knowledge and practice of nutritional fulfillment in pregnant women (Diddana et al, 2018).

\section{METHODS}

This type of research is a pseudo experiment (quasy experiment) that researchers measure variables before the counseling package. The design of this study is Observational Analytics. The samples in this study used a non probability sampling technique of consecutive sampling type, i.e. taking all samples that meet the criteria of inclusion and exclusion during the study. Counseling packages are education, booklets and food samples that can increase weight and LILA is purple yams. Each patient who meets the research criteria is included in the sample for a certain period of time so that the number of subjects required is met in this case 30 pregnant women in the area of Puskesmas Kedungwuni II. Data collection using cheklis food recal taken from kek countermeasure manual with one month of monitoring. Prior to the study, researchers first applied for an ethical clearance to the Ethics Institute of Muhammadiyah University Semarang with certificate no. 168/KEPK-FKM/UNIMUS/2019.

\section{RESULTS}

Table 1 The frequency distribution of respondents based on diet before and after the provision of counseling packages in pregnant women with chronic energy deficiency

\begin{tabular}{lllll}
\hline Diet & Before & \multicolumn{3}{c}{ After } \\
\cline { 2 - 5 } & F & \% & F & \% \\
\hline Good & 14 & 46,7 & 18 & 60 \\
Less & 16 & 53,3 & 12 & 40 \\
\hline & 30 & 100 & 30 & 100 \\
\hline
\end{tabular}


STRADA Jurnal Ilmiah Kesehatan

DOI: $10.30994 /$ sjik.v9i2.399

ISSN: 2252-3847 (print); 2614-350X (online)

Vol.9 No.2 November 2020 Page.944-949

Table 2 Results of analysis of the effect of counseling packages on improving the diet of pregnant women with Chronic Energy Supply

\begin{tabular}{|c|c|c|c|c|c|c|}
\hline Diet & Mean & $\begin{array}{l}\text { Mean } \\
\text { Differen } \\
\mathbf{t}\end{array}$ & p Value & $\mathbf{R}$ & CI Low & CI Upp \\
\hline $\begin{array}{l}\text { Before } \\
\text { After }\end{array}$ & $\begin{array}{l}104,47 \\
142,87 \\
\end{array}$ & 38,13 & 0,001 & 0,001 & 50.361 & 25.906 \\
\hline
\end{tabular}

Table 2 showed that the average diet of respondents prior to counseling package delivery was 104.47 and the average level of anxiety of respondents after the provision of counseling package was 142.87 . There was a significant increase in the average anxiety level in respondents before and after the provision of counseling packages of 142.87 . From the statistical test results using a paired T test obtained a value of $\mathrm{p}=0.001(<0.05)$ with a confidence interval of $95 \%$ it can be concluded that Ho was rejected and Ha accepted which means there is a very significant difference between the diet of respondents before and after the provision of counseling packages against the diet of pregnant women with chronic energy deficiency

\section{DISCUSSION}

The results also showed that the average diet of respondents prior to counseling was 104.47 and the average level of anxiety of respondents after providing counseling packages was 142.87 . There was a significant increase in the average anxiety level in respondents before and after the provision of counseling packages of 142.87 . From the statistical test results using a paired $\mathrm{T}$ test obtained a value of $\mathrm{p}=0.001 \quad(<0.05)$ with a confidence interval of $95 \%$ it can be concluded that Ho was rejected and Ha accepted which means there is a very significant difference between the diet of respondents before and after the provision of counseling packages against the diet of pregnant women with chronic energy deficiency

Pregnancy is a period of rapid growth and cell differentiation, both for the mother and the fetus. Consequently, it is a period when both are very susceptible to alterations in dietary supply, especially of nutrients which are marginal under normal circumstances. The period of intrauterine nourishment, growth and development is one of the most vulnerable periods which affect nutrition status of fetus. Mother's diet should provide adequate nutrients so that maternal stores do not get depleted and the needs of the growing fetus can be met without damaging mother's health. Adequate maternal nutrition plays a key role in normal pregnancy progress, optimal fetal development and normal birth weight of the fetus. Adequate maternal nutrition plays a key role in normal pregnancy progress and optimal fetal development (Maqbool et al, 2019)

A healthy, balanced diet during pregnancy is essential to support optimal growth and development of the fetus and the physiological changes that occur in the mother. Fundamental aspects of healthy dietary behaviors during pregnancy include consuming foods that contain optimal amounts of energy as well as macro and micronutrients, achieving appropriate weight gain, adhering to general and pregnancy-specific food safety recommendations, and avoiding ingestion of harmful substances. Previous studies have shown that if such behaviors are not adopted, there is an increased risk of adverse 


\section{STRADA Jurnal Ilmiah Kesehatan}

DOI: $10.30994 /$ sjik.v9i2.399

ISSN: 2252-3847 (print); 2614-350X (online)

Vol.9 No.2 November 2020 Page.944-949

pregnancy outcomes including low birth weight, preeclampsia, pre-term birth, and neurodevelopmental problems such as fetal alcohol spectrum disorder (Forbes et al, 2018).

As means of intervention, studies have reported that nutrition education was found to have a positive effect on the nutrition awareness of the pregnant women which significantly contributes to improved nutrient intake. In fact, other studies have also established that nutrition education has significant association with good pregnancy outcomes. Antenatal care (ANC) is a key entry point for pregnant women to receive a broad range of health promotion and preventive health services, including nutrition education and support (Nankumbi et al, 2018).

Education is one of the most important resources that enables the family to provide appropriate care for pregnant women and lactating mothers in terms of growth and development

The results of this study are in line with research by Girard \& Olude (2012) which states that counseling can increase intake during pregnancy, even when provided for a short period of time, can be increased. various indicators of the health of mothers and newborns. Diet monitoring after counseling is very important, to see the compliance of pregnant women in fulfilling their diet.

A balanced amount of nutrients is necessary for the proper functioning of the body system. Nutrition is a fundamental pillar of human life, health and development throughout the entire life span1. Proper food and good nutrition are essential for survival, physical growth, mental development, performance and productivity, health, and wellbeing. However, nutrition requirements vary with age, gender, and during physiological changes such as pregnancy. Pregnancy is such a critical phase in a woman's life when the expecting mother needs optimal nutrients of superior quality to support the developing fetus. Malnutrition manifests itself as a function of many and complex factors that affect the national child status 2 . It is directly linked to inadequacy in diet and diseases under living conditions factors that include crisis in household food supply, inappropriate childcare and feeding practices, unhealthy place of residence and insufficient basic health services for those in poor socioeconomic situations, cultural beliefs, and lack of parents' education, especially that of mothers. An adequate nutritional status of pregnant women is essential for their health and pregnancy outcomes (Serbesa, 2019)

As health workers monitor nutritional counseling in chronically deficient pregnant women, bias is carried out at the time of the ANC. Education, counseling and monitoring from health workers is needed to see dietary changes, especially in chronically deficient pregnant women who have to improve diet, especially macro nutrition, especially calories

\section{CONCLUSION}

The conclusion of this study is that there was a very significant difference between the diet of respondents before and after the provision of counseling packages. It is expected for midwives to provide more in-depth counseling and continuous monitoring to pregnant women who are chronically deficient, in order for dietary changes so that nutrition during pregnancy can be met.

\section{REFERENCES}

Castrogiovanni, P., \& Imbesi, R. (2017). The role of malnutrition during pregnancy and its effects on brain and skeletal muscle postnatal development. Journal of Functional Morphology and Kinesiology, 2(3). https://doi.org/10.3390/jfmk2030030 


\section{STRADA Jurnal Ilmiah Kesehatan}

DOI: $10.30994 /$ sjik.v9i2.399

ISSN: 2252-3847 (print); 2614-350X (online)

Vol.9 No.2 November 2020 Page.944-949

Cetin, I., \& Laoreti, A. (2016). The importance of maternal nutrition for health. Journal of Pediatric and Neonatal Individualized Medicine, 4(2), 1-11. https://doi.org/10.7363/040220

Collison, D. K. (2015). Food and Nutrition Technical Assistance III Project Evidence on the Effectiveness of Counseling on Excess Weight Gain during Pregnancy. August.

Danielewicz, H., Myszczyszyn, G., Dębińska, A., Myszkal, A., Boznański, A., \& Hirnle, L. (2017). Diet in pregnancy-more than food. European Journal of Pediatrics, 176(12), 1573-1579. https://doi.org/10.1007/s00431-017-3026-5

Desyibelew, H. D., \& Dadi, A. F. (2019). Burden and determinants of malnutrition among pregnant women in Africa: A systematic review and meta-analysis. PLoS ONE, 14(9), 1-19. https://doi.org/10.1371/journal.pone.0221712

Diddana, T. Z., Kelkay, G. N., Dola, A. N., \& Sadore, A. A. (2018). Effect of Nutrition Education Based on Health Belief Model on Nutritional Knowledge and Dietary Practice of Pregnant Women in Dessie Town, Northeast Ethiopia: A Cluster Randomized Control Trial. Journal of Nutrition and Metabolism, 2018. https://doi.org/10.1155/2018/6731815

Forbes, L. E., Graham, J. E., Berglund, C., \& Bell, R. C. (2018). Dietary change during pregnancy and women's reasons for change. Nutrients, 10(8), 1-10. https://doi.org/10.3390/nu10081032

Girard, A. W., \& Olude, O. (2012). Nutrition education and counselling provided during pregnancy: Effects on maternal, neonatal and child health outcomes. Paediatric and Perinatal Epidemiology, 26(SUPPL. 1), 191-204. https://doi.org/10.1111/j.13653016.2012.01278.x

Koenig, M. D. (2017). Nutrient Intake During Pregnancy. JOGNN - Journal of Obstetric, Gynecologic, and Neonatal Nursing, 46(1), 120-122. https://doi.org/10.1016/j.jogn.2016.11.004

Lucas, C., Charlton, K. E., \& Yeatman, H. (2014). Nutrition Advice During Pregnancy: Do Women Receive it and Can Health Professionals Provide it? Maternal and Child Health Journal, 18(10), 2465-2478. https://doi.org/10.1007/s10995-014-1485-0

Maqbool, M., Dar, M. A., Gani, I., Mir, S. A., Khan, M., \& Bhat, A. U. (2019). Maternal Health and Nutrition in Pregnancy: an Insight. World Journal of Pharmacy and Pharmaceutical Sciences, 8(3), 450-459. https://doi.org/10.20959/wjpps20193-13290

Mersal, F. A., Esmat, O. M., \& Khalil, G. M. (2013). Effect of prenatal counselling on compliance and outcomes of teenage pregnancy. Eastern Mediterranean Health Journal, 19(1), 10-17. https://doi.org/10.26719/2013.19.1.10

Morrison, J. L., \& Regnault, T. R. H. (2016). Nutrition in pregnancy: Optimising maternal diet and fetal adaptations to altered nutrient supply. Nutrients, 8(6), 3-7. https://doi.org/10.3390/nu8060342

Nankumbi, J., Ngabirano, T. D., \& Nalwadda, G. (2018). Maternal Nutrition Education Provided by Midwives: A Qualitative Study in an Antenatal Clinic, Uganda. Journal of Nutrition and Metabolism, 2018. https://doi.org/10.1155/2018/3987396

Rahfiludin, M. Z., \& Dharmawan, Y. (2019). JOURNAL OF PUBLIC HEALTH FOR TROPICAL AND COASTAL Description of Daily Nutritional Intake of Pregnant Women in Temanggung District, Central Java, Indonesia . 1. 